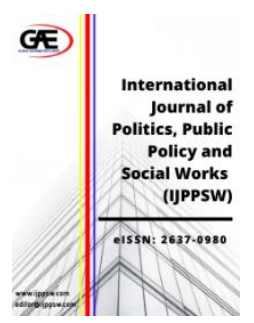

\author{
INTERNATIONAL JOURNAL OF \\ POLITICS, PUBLICS POLICY \\ AND SOCIAL WORKS \\ (IJPPSW) \\ www.ijppsw.com
}

\title{
A MIXED-METHOD EVALUATION OF THE FINANCIAL AID SYSTEM FOR DISABLED PERSONS IN MALAYSIA
}

\author{
Muhamad Nadhir Abdul Nasir ${ }^{1 *}$ \\ 1 Department of Anthropology and Sociology, University of Malaya, Malaysia \\ Email: anndh91@gmail.com \\ Corresponding Author
}

\section{Article Info:}

Article history:

Received date: 25.02 .2021

Revised date: 10.03.2021

Accepted date: 12.03 .2021

Published date: 15.03.2021

\section{To cite this document:}

Nasir, M. N. A. (2021). A MixedMethod Evaluation of The Financial Aid System for Disabled Persons in Malaysia. International Journal of Politics, Publics Policy and Social Works, 3 (8), 13-28.

DOI: $10.35631 /$ IJPPSW.38002.

This work is licensed under $\underline{\text { CC BY } 4.0}$

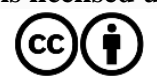

\begin{abstract}
:
In the midst of the COVID-19 pandemic outbreak, one poignant issue hotly discussed is the social protection of the citizens, especially financial aid for poor and marginalized groups. Regardless of the recent increase in the amount of financial aid for certain sets of disabled persons in Malaysia, the present study interrogates broader structural issues and implications concerning the financial aid system for disabled persons as a whole. This study draws its data from a content analysis of the eligibility criteria of selected financial aid programs and feedback from the grassroots community. Most respondents from the online survey admit that they still need financial aid to sustain their survival. They also agree that the current financial aid system needs to be changed. In determining the financial aid amount, the top three determinants are having a chronic illness, the number of dependants, and employment status. Equally notable, most respondents disagree with gender as one of the determinants. The content analysis, on the other hand, reveals that few requirements and the overall financial aid model no longer reflect the current situation. In each financial aid program, there exist direct and indirect layers of biopower. Policies on financial aid for disabled persons and the social protection system, in general, must be revamped. At the end of this article, multi-pronged solutions are discussed.
\end{abstract}

Keywords:

Biopower, Disabled Persons, Financial Aid System, Mixed-Method, Social Protection

\section{Introduction}

The COVID-19 pandemic, which began in early 2020 and continuously spreading in 2021, forces the governments and global society to rethink and reconfigure many aspects of our daily life. Much of the important issues are being discussed within the scholarly and activism sphere, such as policy response (see for example Lim \& Wong, 2021), emergency powers and Copyright $\odot$ G GOBAL ACADEMIC EXCELLENCE (M) SDN BHD - All rights reserved 


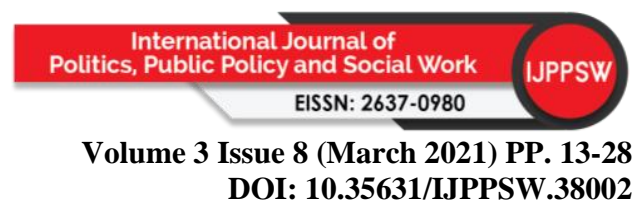

measures (see for example Chen, 2021; Rumpia, 2021; Santamaria, 2021; Sison, 2021), democracy (see for example Pinol, 2021; Tantirapan, 2021), armed conflict (Abo \& Ayao, 2021), as well as health and social protection (see for example Basrianto, 2021; Juwitasari, 2021; Nguyen, 2021).

One small, but very popular topic is the discussion on financial aid for the citizens who are struggling to make ends meet and sustain their livelihood due to job losses caused by lockdown or movement control order. In Malaysia, besides the rollout of various economic incentive plans, such as PRIHATIN, PENJANA, and PERMAI, there is also a suggestion to raise the amount of welfare financial aid, most notably a suggestion by the Prime Minister himself ("PM Cadang Naikkan Kadar Bantuan," 2020). This particular topic re-highlights the long-debated issue amongst disabled persons as it involves the very survival of most disabled individuals who are struggling even before the COVID-19 pandemic outbreak.

This paper discusses the financial aid system for disabled persons in Malaysia by comparing the feedback from the grassroots community and the analysis of eligibility requirements of selected financial aid programs. For this study, financial aid is defined as monetary assistance provided by the government that seeks to support the daily living of disabled persons, and do not include financial aid programs for specific purposes such as business creation or acquiring assistive device. After reviewing past literature, the paper continues to explain the research methodology and then presents the data gathered. Afterward, the author expounds the findings in the framework of social protection, linking to relevant international and local documents, as well as makes recommendations to improve the overall wellbeing of disabled Malaysians.

\section{Literature Review}

Besides the greater risk of infection, the COVID-19 pandemic disrupts access to services among persons with impairment and/or chronic illness and threatens their livelihood (Banks, Davey, Shakespeare, \& Kuper, 2021; Romano, 2020; Senjam, 2020; UN Human Rights, 2020). Worst, persons with impairment and/or chronic illness face eugenic ideology and practices concerning the treatment and the provision of appropriate medical equipment (Nelson, Ram, \& Majumder, 2020; Sabatello, Landes, \& McDonald, 2020). It is not an exaggeration to say that many parts of the social, economic, and political structures which govern and shape our lives for many centuries must be reviewed and reformed, particularly in relation to persons with impairment and/or chronic illness.

One specific aspect is the social protection and adequate standard of living of persons with impairment and/or chronic illness. It seems direct cash transfer is the most common method used to decrease the economic and social impact of the COVID-19 pandemic among persons with impairment and/or chronic illness, besides the distribution of food and other essential goods. However, in some countries, only certain subsets of persons with impairment and/or chronic illness are eligible to receive such aids and they also confront rigid bureaucratic problems (Banks, Davey, Shakespeare, \& Kuper, 2021; Romano, 2020).

In South Asian countries, for example, there are many challenges concerning social protection measures to mitigate the impact of the pandemic on disabled persons. These include inadequate outreach activities, lack of specific social protection programs, barriers in information and communication services, and lack of proactive measures by the governments (Balasubramanian, 2021). To provide better social protection for persons with impairment and/or chronic illness, some suggests the development of community-based services, ensuring Copyright @ GLOBAL ACADEMIC EXCELLENCE (M) SDN BHD - All rights reserved 


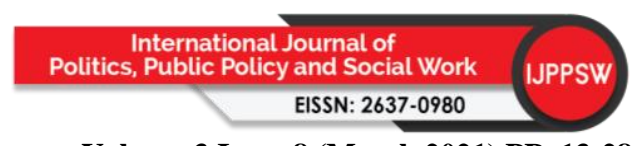

Volume 3 Issue 8 (March 2021) PP. 13-28

DOI: 10.35631/IJPPSW.38002

access to information, and greater emphasis on the participation of the disabled community in the design, implementation, and monitoring of social protection measures (Balasubramanian, 2021; Romano, 2020).

In addition to administrative and legislative measures, the government must view the design and implementation of a social protection system for disabled persons as a combination of financial aid and services (Balasubramanian, 2021). Beyond that, specific social protection programs and aids for disabled persons must be made an integral part of broader social protection and economic systems such as housing, decent work, education, as well as health and childcare (Adato \& Bassett, 2009; Brucker \& Scally, 2015). In other words, we must interrogate social protection programs, not only in relation to one impairment group to another but contextualize the problem in different sub-dimensions in society and the nation's socioeconomic climate.

Even with the design and delivery of financial aid packages, careful consideration must be given by taking into account (i) the differing needs and its degree between persons with impairment and/or chronic illness, without neglecting the reality that one's needs may evolve from time to time; (ii) it is fact that persons with impairment and/or chronic illness require a certain essential resources, maybe more than their non-disabled counterparts, to level the playing field; (iii) the significance of human services (Smith, Middleton, Ashton-Brooks, Cox, Dobson, \& Reith, 2004, pp. 68-71).

Based on a systematic review of studies relating to the cost of living among disabled persons, it is observed that (i) the estimated cost of living among disabled persons are substantial; (ii) the estimated cost of living varies according to one's severity of impairment, age, and household composition; (iii) higher cost can be seen among persons with a moderate or severe degree of impairment, as well as disabled persons who live alone or in a small household (Mitra, Palmer, Kim, Mont, \& Groce, 2017). In Cambodia, it is observed that families with members with impairment also shoulder extra costs of living just to achieve a similar standard of living as other families (Palmer, Williams, \& McPake, 2016).

Therefore, the social protection system and its affiliated programs must take into account these factors and realities, adopting a disaggregated inclusion approach in the design of such programs and not generalizing various needs into a single bracket (Nasir, 2020, p. 80). With this consciousness in mind, the present study seeks to interrogate the financial aid system for disabled Malaysians to be more reflective of its beneficiaries' needs and circumstances.

\section{Methodology}

The present study utilizes an explanatory mixed-method research design, in which the data collection process begins with an online questionnaire (a quantitative method) follows by content analysis of eligibility criteria of selected financial aid programs for disabled persons in Malaysia (a qualitative method). The online questionnaire is developed using Google Form application which contains three main sections: respondent's demographic information, respondent's perception towards current financial aid system, and respondent's perception of new financial aid model for disabled persons in Malaysia.

The online questionnaire is disseminated via WhatsApp and Facebook platforms. The researcher disseminates the online survey either through WhatsApp and Facebook groups which comprise of disabled persons as well as to a selected number of disabled individuals, all Copyright (C) GLOBAL ACADEMIC EXCELLENCE (M) SDN BHD - All rights reserved 
Volume 3 Issue 8 (March 2021) PP. 13-28 DOI: $10.35631 /$ IJPPSW.38002

of them are leaders in their community, to fill up and further disseminate the online survey to other disabled people in their network. Meaning, the study combines purposive sampling, cluster sampling, and snowball technique to acquire a larger number of research participants. The online survey targets those who are Malaysian citizens, registered as disabled persons, and aged 18 years old and above.

The online survey begins on January $9^{\text {th }}, 2021$ and ends on February $17^{\text {th }}, 2021$. The researcher sends out the call for participation periodically, distancing the posts between 7-9 days apart to avoid confusion. Participation in the survey is voluntary and no token of participation is given to research participants. 155 respondents take part in the survey. Of these, 58 respondents are female (37.4\%) and 97 are male respondents (62.6\%). With regards to ethnicity, 103 respondents are Malay (66.5\%), 20 respondents are Chinese (12.9\%), 17 respondents are Indian $(11 \%)$, and the remaining 15 respondents represent other ethnicities $(9.6 \%)$. The research participants are also diverse in terms of age group, category of impairment, marital status, and employment status as shown in Tables 1,2, and 3 below.

Table 1: Respondents' Age Group

\begin{tabular}{cc}
\hline Age range & Number of respondents \\
\hline $18-30$ years old & 51 \\
$31-40$ years old & 43 \\
$41-50$ years old & 38 \\
$51-60$ years old & 15 \\
61 years old and above & 8 \\
\hline
\end{tabular}

Table 2: Respondents' Category of Impairment

Category of impairment Number of respondents

Physical impairment 78

Hearing impairment 21

Visual impairment 43

Speech impairment 1

Learning disabilities 4

Mental health problem 4

Multiple impairments 4

Table 3: Respondents' Marital Status

Marital status Number of respondents

Single 85

Married $\quad 58$

Divorced 12

Table 4: Respondents' Employment Status

\begin{tabular}{cc}
\hline Employment status & Number of respondents \\
\hline Student & 15 \\
Working in the public sector & 18 \\
Working in the private sector & 30 \\
Working in an NGO & 6 \\
Doing business or self-employed & 42 \\
Retiree & 6 \\
\hline
\end{tabular}




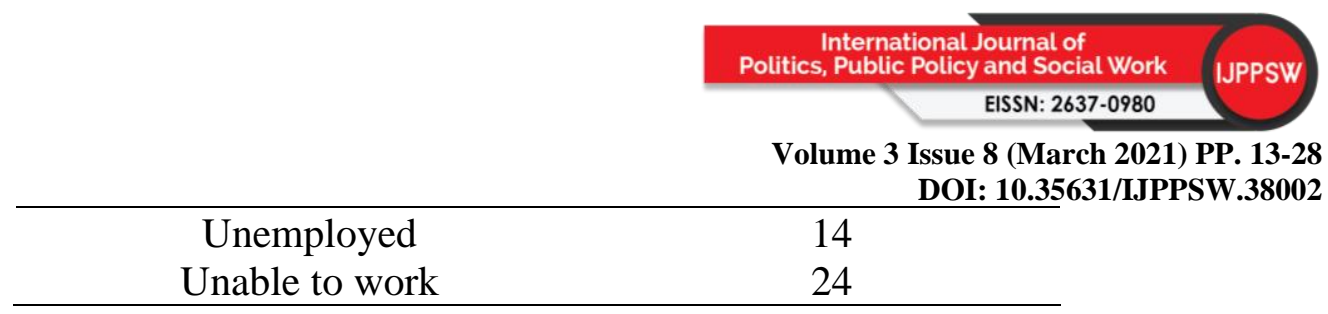

After collecting and analyzing data gathered from the online survey, the researcher examines the eligibility criteria of selected financial aid programs for disabled persons in Malaysia. These financial aid programs are disabled worker allowance (EPC), assistance for unemployed disabled persons (BTB), and a living stipend for disabled university students. The analysis not only concerns the explicit written criteria for applicants but also interrogates the implications of such criteria (direct and indirect), as well as the existence of third-party power and control over the applicants and the application process.

Using a descriptive analysis of the quantitative data and Foucauldian analytical framework for the qualitative data, the researcher hopes to present the current situation of the financial aid system for disabled persons in Malaysia and offer the re-imagination and reconfiguration of the social protection ecosystem for this group and Malaysians as a whole. Despite that, the findings from this study must not be generalized due to its limitation in the sample size.

\section{Feedback From the Grassroots Community}

The researcher designs the online questionnaire to test four main hypotheses. Those hypotheses are:

Hypothesis A: Most respondents still need financial aid from the government for their current survival.

Hypothesis B: Most respondents are aware that financial aid is only a short-term solution.

Hypothesis C: Most respondents agree that the current financial aid system for disabled persons in Malaysia must be changed.

Hypothesis D: Most respondents agree that factors such as gender, age group, degree of impairment, income, number of dependants, and having a chronic illness are important in determining the amount of financial aid given to a disabled person.

To begin, it is important to present the number of respondents who receive financial aid from the government and what type of financial aid they received. As shown in Table 5, 70 respondents $(45.2 \%)$ disclose that they still receive financial aid from the government. Interestingly, 28 respondents $(18.1 \%)$ admit that they receive financial aid before, but no longer eligible to claim such aid, while 16 respondents (10.3\%) admit that they want to apply but aware of their ineligibility.

Table 5: Number of Respondents Receiving Government Financial Aid

\begin{tabular}{cc}
\hline Statement & Number of respondents \\
\hline Never applied & 22 \\
Wanted to apply but wasn't eligible & 16 \\
Applied, but rejected & 19 \\
Received it before, but no longer eligible to apply & 28 \\
Still receive financial aid & 70 \\
\hline
\end{tabular}


In the survey, the researcher separates the question of what type of financial aid one applies for and what type of financial aid one receives. This is because, one may apply for more than one financial aid, but only one application will be approved. The researcher must note that for these questions, respondents can tick more than one option. As Table 6 and Table 7 suggest, the Disabled Worker Allowance is the top financial aid applied for and received among most respondents. Comparing data from Table 6 and Table 5, there is a discrepancy between the number of "never applied" in Table 5 and the number of those who "never applied any of the above" in Table 6.

One possible explanation is that some of the respondents apply for other financial aid programs which are not listed in the survey, either monetary aid under the federal government or state government. A comparison between data from Table 6 and Table 7 also shows some respondents may receive assistance from others, knowingly or unknowingly, in applying for some financial aid programs, such as the Allowance for CBR Trainee and Learning Encouragement Allowance for PLPP Trainee. This may be explained by the fact that both trainees will automatically receive such allowance without having to face the bureaucratic hassle one may face when applying for other financial aid programs.

Table 6: Types of Financial Aid Applied

\begin{tabular}{cc}
\hline Financial aid program & Number of respondents \\
\hline Disabled Worker Allowance & 79 \\
Assistance for Unemployed Disabled Person & 33 \\
Allowance for CBR Trainee & 0 \\
Learning Encouragement Allowance for PLPP Trainee & 0 \\
Living Stipend for Disabled University Student & 24 \\
Allowance for Disabled Trainee at Vocational Training Center & 2 \\
Never applied any of the above & 35 \\
\hline
\end{tabular}

Table 7: Types of Financial Aid Received

\begin{tabular}{cc}
\hline Financial aid program & Number of respondents \\
\hline Disabled Worker Allowance & 70 \\
Assistance for Unemployed Disabled Person & 28 \\
Allowance for CBR Trainee & 2 \\
Learning Encouragement Allowance for PLPP Trainee & 1 \\
Living Stipend for Disabled University Student & 26 \\
Allowance for Disabled Trainee at Vocational Training Center & 3 \\
Never received any of the above & 43 \\
\hline
\end{tabular}

Next, the online survey inquires respondents to select one or more challenges relating to the current financial aid system for disabled persons in Malaysia. As illustrated by Table 8 below, the top six challenges are: (a) Eligibility requirements are not in line with the current situation of disabled persons; (b) Not all disabled persons eligible to receive aid; (c) Insufficient amount of assistance; (d) Application process is difficult; (e) Long approval period; and, (f) Have to renew the application for aid in a certain period. 
Volume 3 Issue 8 (March 2021) PP. 13-28

DOI: $10.35631 /$ IJPPSW.38002

Table 8: Challenges of Current Financial Aid System

\begin{tabular}{cc}
\hline Challenges & Number of respondents \\
\hline Insufficient amount of assistance & 67 \\
Eligibility criteria are not in line with the current situation & 75 \\
The application process is difficult & 66 \\
Long approval period & 64 \\
Not all disabled person can receive it & 75 \\
Have to renew the application in a certain period & 61 \\
The renewal process is difficult & 36 \\
Difficulty to find accurate information & 28 \\
\hline
\end{tabular}

Besides the challenges listed above, some respondents also put forward additional problems regarding the current financial aid system. Some of those additional inputs are (i) difficulty in contacting the officers in charge of the application process, or unpleasant treatment received from those officers; (b) inconsistent schedule of financial aid distribution between states and persons; and, (c) the financial aid does not take into account the needs of persons with a different impairment.

Subsequently, respondents are asked about their attitude towards financial aid and its system as a whole. Based on the data illustrated in Table 9, Hypothesis A, which most respondents still need financial aid for their current survival is confirmed, where 112 respondents $(72.3 \%)$ agree and strongly agree that they need financial help to sustain their livelihood at the time of data collection.

Furthermore, 126 respondents $(81.3 \%)$ feel that the disabled community in Malaysia as a whole still in need of government financial assistance, though 82 respondents (52.9\%) agree and strongly agree that financial aid is only a short-term solution, confirming the second hypothesis. On the other hand, 32 respondents $(20.6 \%)$ only agree with the same statement to some extent, which they may feel such a statement only applicable in certain contexts and should not be generalized to all disabled persons. At the same time, 111 respondents $(71.6 \%)$ agree and strongly agree that the wellbeing of disabled persons in Malaysia demands efforts beyond financial assistance by the government.

Table 9: Attitude Towards Current Financial Aid System

\begin{tabular}{ccccccc}
\hline Statements & \multicolumn{5}{c}{ Number of respondents } \\
\cline { 2 - 6 } & Strongly & Disagree & $\begin{array}{c}\text { Agree to } \\
\text { disagree } \\
\text { extent, but } \\
\text { disagree } \\
\text { with others }\end{array}$ & $\begin{array}{c}\text { Agree } \\
\text { Strongly } \\
\text { agree }\end{array}$ & $\begin{array}{c}\text { No } \\
\text { opinion }\end{array}$ \\
\hline $\begin{array}{c}\text { I desperately need } \\
\text { financial help to } \\
\text { sustain my living at } \\
\text { this time }\end{array}$ & 5 & 6 & 24 & 38 & 74 & 8 \\
$\begin{array}{c}\text { The disabled } \\
\text { community in }\end{array}$ & 83 & 43 & 19 & 3 & 2 & 5 \\
$\begin{array}{c}\text { Malaysia as a whole } \\
\text { no longer needs }\end{array}$ & & & & & & \\
\hline
\end{tabular}


financial assistance

from the government

The provision of

financial assistance

causes disabled

persons in Malaysia

to depend solely on

government

assistance

The existing financial

aid system is very

easily manipulated by

irresponsible people

The financial

assistance system for disabled persons in

Malaysia needs to be changed

All registered

disabled people

should receive

financial assistance automatically

Financial assistance is

only a short-term solution

The well-being of

disabled persons in

Malaysia demands

efforts beyond

financial assistance

from the government
42

19

11

4

16

21

29

42

23

24

3

6

28

59

49

10

2

8

33

42

67

3

14

22

32

55

27

5

3

3

27

66

45

11

Besides that, only 30 respondents (19.4\%) agree and strongly agree the provision of financial assistance causes disabled persons to be dependent on government aid, while 42 respondents (27.1\%) agree with the statement to some extent. However, 65 respondents (41.9\%) agree and strongly agree that the current financial aid system is very easily manipulated by irresponsible parties, whereas 29 respondents $(18.7 \%)$ agree to some extent and 24 respondents $(15.5 \%)$ have no opinion on such matter.

From the feedback on the challenges of the current financial aid system, it is not surprising to see 108 respondents $(69.7 \%)$ agree and strongly agree that the current financial aid system needs to be changed. This confirms Hypothesis C. Interestingly, 28 respondents (18.1\%) agree to some extent. This may be because they feel only some parts of the current financial aid system need to be changed. Following that, 109 respondents (70.3\%) agree and strongly agree that all registered disabled persons must receive financial aid automatically, whereas 33 respondents $(21.3 \%)$ agree with the statement to some extent. 
Volume 3 Issue 8 (March 2021) PP. 13-28 DOI: 10.35631/IJPPSW.38002

Finally, the online survey collects respondents' feedback on a new model for financial aid system for disabled persons in Malaysia based on a number of determinants. There are nine proposed determinants listed in the online survey. As shown in Table 10 below, 92 respondents (59.4\%) disagree and strongly disagree to consider the gender factor as a determinant of financial aid amount for a disabled person. The other determinants receive quite favorable support among most respondents. The top three determinants are having a chronic illness, the number of dependants, and employment status.

Table 10: Feedback on New Financial Aid Determinants

\begin{tabular}{ccccccc}
\hline Determinants & \multicolumn{5}{c}{ Number of respondents } \\
\cline { 2 - 7 } & $\begin{array}{c}\text { Strongly } \\
\text { disagree }\end{array}$ & Disagree & $\begin{array}{c}\text { Agree to } \\
\text { some extent, } \\
\text { but disagree } \\
\text { with others }\end{array}$ & $\begin{array}{c}\text { Agree } \\
\text { Strongly } \\
\text { agree }\end{array}$ & $\begin{array}{c}\text { No } \\
\text { opinion }\end{array}$ \\
\hline $\begin{array}{c}\text { Gender } \\
\text { Degree of }\end{array}$ & 36 & 56 & 21 & 23 & 13 & 6 \\
$\begin{array}{c}\text { impairment (mild, } \\
\text { moderate, severe) }\end{array}$ & 14 & 33 & 24 & 44 & 32 & 8 \\
$\quad \begin{array}{c}\text { Type of } \\
\text { impairment }\end{array}$ & 17 & 28 & 23 & 48 & 35 & 4 \\
$\begin{array}{c}\text { Age group } \\
\text { Employment }\end{array}$ & 10 & 23 & 29 & 56 & 31 & 6 \\
$\quad \begin{array}{c}\text { status } \\
\text { Having a chronic }\end{array}$ & 4 & 13 & 19 & 63 & 47 & 6 \\
$\begin{array}{c}\text { illness } \\
\text { Marital status }\end{array}$ & 12 & 3 & 15 & 77 & 48 & 8 \\
$\begin{array}{c}\text { Monthly income } \\
\text { Number of } \\
\text { dependants }\end{array}$ & 10 & 19 & 25 & 51 & 37 & 11 \\
\hline
\end{tabular}

This partially confirms Hypothesis D, in which gender is not considered as a determinant and is replaced by employment status. Interestingly, even though other determinants receive a high score, those determinants are not equally favorable as the top three determinants; having a chronic illness, the number of dependants, and employment status. Notwithstanding the number of respondents who agree to some extent on these determinants, one plausible explanation is that some respondents may not able to quantitatively equate certain determinants (e.g. type of impairment and degree of impairment) to a material amount of financial assistance.

\section{The Analysis of the Eligibility Criteria}

To complement the quantitative data gathered via the online survey, the researcher conducts a content analysis of eligibility criteria of selected financial aid programs. Those are Disabled Worker Allowance, Assistance for Unemployed Disabled Person, and Living Stipend for Disabled University Student. I employ a Foucauldian analytical questioning to facilitate the analysis, which composes of the following questions:

1. What are the requirements that a person with impairment must meet to apply for such aid? 


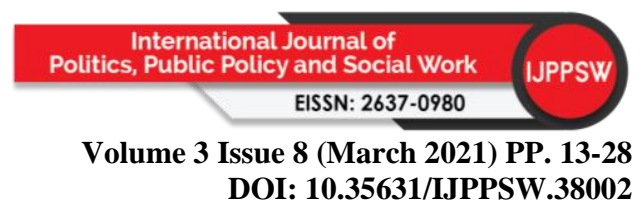

2. What are the direct and indirect implications of such requirements to the person?

3. Who are internal and external parties involved in the process?

4. What effects or power can be imposed by these internal and external parties on the person?

According to the information provided on the official portal of Jabatan Kebajikan Masyarakat Malaysia (2021b), the Disabled Worker Allowance is an incentive to encourage disabled persons to continue working, besides live independently and become productive members of society. There are four main requirements one must meet to be eligible to apply for such aid. First, one must be a citizen, resident, and working in Malaysia. Second, the applicant must be 16 years old and above. Third, the applicant must be a registered disabled person, and finally, he or she must earn a monthly income of RM1,200.00 and below. The Director-General of Social Welfare may consider and approve any special cases.

One major criticism towards this program, which many if not most agree on, is the fact that only those who earn RM1,200.00 or less can apply for such aid. Recently, the poverty line in Malaysia has been revised from RM980.00 to RM2,208.00 (Mohamad, 2020; Wartawan MalaysiaGazette, 2020), which inflates more than 100\%. Consequently, those who barely earn more than RM1,200.00, although he or she has to bear extra costs of living, increasingly feel the pressure. One plausible alternative is to provide a certain amount of financial aid between different income brackets and those who earn more than a certain amount must not be eligible to receive the assistance.

Usually, when the requirement explicitly states the word "earning", the applicant shall bear the burden to prove his monthly income in writing. This may complicate those who work in informal employment without an "official" payslip. Although there may be some discretionary, the risk of rejection is higher. This brings us to those who have power or control over the process. The social welfare officers have direct power over the application by exercising their authority given by the procedures. For those who are considered unconventional applicants, another figure of power will be involved, which is the Director-General of Social Welfare. Finally, as the applicant must be a registered disabled person, he or she must first prove his or her existence of impairment according to the guidelines and approved by a medical officer. This adds another layer of distal biopower over the application process.

For disabled persons who are unable to work, the government provides a special assistance scheme called Assistance for Unemployed Disabled Persons that aims to assist this group of people and encourage them to live with their family (Jabatan Kebajikan Masyarakat Malaysia, 2021a). The main requirements are similar to the Disabled Worker Allowance scheme, such as one must be a citizen of and resides in Malaysia, aged 16 years old and above, as well as a registered disabled person. Besides unable to work, the applicant must not be a resident or coach at any institutions operated by the Department of Social Welfare or daycare/residential center that provides free services/facilities, or a community-based rehabilitation center. In addition, the applicant's monthly financial resources, which include pensions, benefits, or assistance, must not exceed the current poverty line. Finally, the Director-General of Social Welfare may consider and approve special cases. 


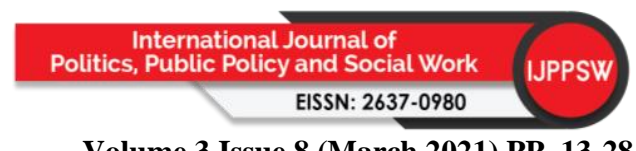

Volume 3 Issue 8 (March 2021) PP. 13-28

DOI: $10.35631 / I J P P S W .38002$

Though it seems to differ from the Disabled Worker Allowance on the surface, in truth, the same distal and proximal layers of biopower exist (i.e. the Director-General of Social Welfare, social welfare officer, and medical officer). Plus, one's affiliation with a certain pre-identified institution may also affect his or her eligibility to receive the Assistance for Unemployed Disabled Person program since the aim of the program supposedly encourages the beneficiaries to live with their families. Maybe, the government wants to ensure efficient distribution of financial aid to those who are eligible and do not want to over-burden their expenditure, but it is imperative to assess whether these institutions provide appropriate and sufficient services and facilities to their residents/clients. Moreover, both programs, the Disabled Worker Allowance and the Assistance for Unemployed Disabled Person do not recognize the differing needs and their degree among its beneficiaries.

The next related question is, do disabled persons who live alone and unable to work eligible to apply for this aid since the main goal for the Assistance for Unemployed Disabled Person program is for the recipients to live with their family members? Disabled persons, especially adults have the right to determine their living arrangement, either living with family members, friends, or alone. This situation highlights the neoliberalized relationships between unemployment, productivity, and a narrow sense of familial interdependence, causing the lack of access to social protection and life insecurities to be perceived as personal problems that have no tie to systemic and structural failures in society.

Under the Ministry of Higher Education, there is a specific financial aid program for disabled university students called the Financial Assistance for Disabled Persons in Higher Learning Institution. This program consists of two main components: living stipend and tuition fee assistance. But, since the focus of the present study is to examine financial aid programs that provide general support of the daily living of disabled individuals and not for specific purposes, I shall focus my analysis on the former. According to the information provided on the official portal of Kementerian Pengajian Tinggi (2021), although the disabled student may receive a scholarship or other facilities that are also enjoyed by non-disabled students, the disabled student still eligible to receive this allowance. Plus, this special aid does not take into account income status as part of its requirements.

This program is open to all disabled students who are pursuing tertiary education, from diploma level and above, at any higher learning institutions under the management and control of the Ministry of Higher Education, which include public and private higher learning institutions, polytechnics, and community colleges. Those who are pursuing long-term certificate level courses at polytechnics and community colleges under the responsibility of the Ministry of Higher Education may also be considered. This assistance period is subject to the original offer letter and does not exceed the maximum period of assistance as follows:

(i) Certificate level - 2 years. This is only for disabled students at community colleges and polytechnic. The financing limit is RM5,000.00 up to RM10,000.00.

(ii) Diploma level -3 years. The financing limit is RM5,000.00 up to RM15,000.00.

(iii) Bachelor level -4 years. The financing limit is RM5,000.00 up to RM20,000.00.

(iv) Postgraduate diploma level -2 years. The financing limit is RM5,000.00 up to RM10,000.00.

(v) Master level - 2 years. The financing limit is RM5,000.00 up to RM10,000.00.

(vi) Ph.D. level - 4 years. The financing limit is RM5,000.00 to RM20,000.00. 


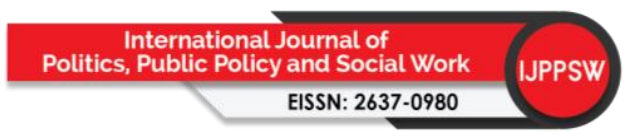

Volume 3 Issue 8 (March 2021) PP. 13-28

DOI: 10.35631/IJPPSW.38002

Besides the basic requirement of Malaysian citizenship, the disabled students must register as disabled persons with the Department of Social Welfare and have the Kad OKU. The disabled students must pursue courses that are recognized by the Malaysian Qualifications Agency or the Public Service Department. Students attending part-time courses or distance learning are eligible for this financial assistance, however, those who are on a paid study leave period (full or partial) are not eligible. Those who are applying for an extension are also not eligible.

Essentially, disabled students who receive education loans or self-financing their studies are eligible to receive a living stipend and tuition fee assistance. The assistance rate for the living stipend is RM300.00 per month and the balance is then channeled for tuition fee assistance subject to RM5000 per year for both components. Similar to the previous financial aid programs discussed above, the amount, as well as the criteria of distribution, fails to reflect the diverse degree of needs among students with different types and degrees of impairment. Besides that, Disabled students who want to apply for this aid are subject to more layers of biopower that applicants have to navigate through. First, many disabled students, if not most of them, have to obtain information and relevant forms from the officers charged with disabled students' affairs in their respective institutions.

Then, the students must make sure that his or her study program is recognized by the Malaysian Qualification Agency. This may pose greater obstacles for those who are pursuing a study program in a private higher learning institution. Finally, the students depend on the officers at the Ministry of Higher Education responsible for receiving and processing the applications. Some may go back and forth between officers at their universities and officers at the ministry to ensure their application is accepted. Some may take a direct approach by directly contacting the officers at the ministry.

Disabled students who extend their studies for any reason are not eligible to receive this aid despite their circumstances. This highlights the neoliberalized managerialistic episteme and system in higher education, where everyone is expected to have a similar pattern of capacities to achieve pre-determined merits at the same speed and level of performance. Not only its persistent emphasis shifts away from the discussion about the duties of institutions and the systemic failures, but it may also potentially harm marginalized groups such as students with autism, learning disabilities, or those who have brain traumatic injuries.

Though this study only concerns the living stipend component, the researcher is acutely aware of many weaknesses of the financial aid program for disabled university students. Indeed, a thorough study of the whole program is needed to ensure the policy reflects the real needs of university students with different types of impairment and levels of studies.

\section{Discussion}

From the findings obtained, it is evident that there is no clear reasoning for a certain amount of financial aid given in each program despite persons with impairment and/or chronic illness have diverse levels of needs besides the extra costs of living they bear. Moreover, the respondents struggle to navigate the application process which may cause by different layers of authority, directly or indirectly. Government financial aid is usually perceived as special privileges, generous aid, or handout, causing the recipients looked down on and (consciously or unconsciously) disrespected by others. 


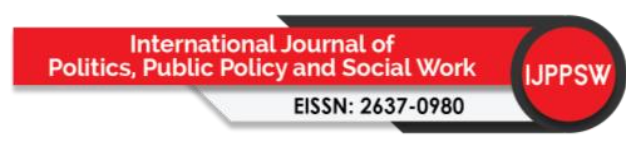

Volume 3 Issue 8 (March 2021) PP. 13-28

DOI: $10.35631 /$ IJPPSW.38002

Everyone has the right to social protection. This is expressly mentioned through Article 22 and Article 23 of the Universal Declaration of Human Rights. The Convention on the Rights of Persons with Disabilities reaffirms this right through Article 28 which recognizes and emphasizes the right of disabled persons to an adequate standard of living and social protection. Unfortunately, the Persons with Disabilities Act 2008 do not contain such clauses, though there is a specific section that guarantees support for those with severe impairment. Although social protection of disabled Malaysians may be ensured through other sections in the law (e.g. sections on habilitation and rehabilitation), it is imperative for specific clauses on social protection to be integrated, at least in the Persons with Disabilities Act 2008.

The commodification of human needs across different life dimensions causes adequate standard of living and social protection are measured and designed in monetary form. Hence, the by-product is to provide financial aid to poor and marginalized groups who are structurally hampered to achieve such standards, as the best and fastest way to alleviate poverty. The author asserts that current and future discussions about the economic system must be reconceptualized which human needs should be put as central focus (Nasir, 2020; p. 80), which then inform our policies and reconfigure the economic system in Malaysia.

The financial aid programs for disabled persons should not be designed using a neoliberal and charity mindset. It can be revolutionized to uphold the human rights of persons with impairment and/or chronic illness. The same goes for the social protection system in Malaysia. The author advocates for (i) the improvement of the financial aid system for disabled persons using the disaggregated inclusion approach; and, (ii) the enablement of social and economic system in Malaysia so disabled persons can meaningfully develop themselves and contribute to the community.

Two immediate actions can be carried out. First, the government must review and revamp the design of financial aid programs that aim to support disabled persons' livelihood. To this end, the author recommends a new model of financial aid system for disabled Malaysians, known as the "Disabled People Life Security Scheme" (Skim Jaminan Sara Hidup Orang Kurang Upaya) to replace all three above-mentioned financial aid programs. This scheme will be given automatically to all registered disabled persons and the amount of the financial aid is determined using the most relevant determinants. Second, other financial aid programs with specific objectives such as business creation, business expansion, tuition fees, and assistive devices must also be reviewed and revamped.

Simultaneously, as a medium-term initiative, the government through close engagement with organizations for and of disabled persons, must formulate, develop, and implement various public services and facilities which are free or low cost for disabled persons. These include the establishment of a sign language interpretation system as part of public social services (Nasir \& Efendi, 2020a), the introduction of public community housing for destitute people (Nasir \& Efendi, 2020b), and so forth. The government should also take this opportunity to re-examine and streamline the service network of community-based rehabilitation centers, independent living centers, and home help services into a comprehensive and systematic social protection ecosystem.

\section{Conclusion}

Based on the feedback received and the analysis of the eligibility criteria, the current financial aid system for disabled persons in Malaysia must be reviewed and improved. As supported by Copyright $($ C GLOBAL ACADEMIC EXCELLENCE (M) SDN BHD - All rights reserved 


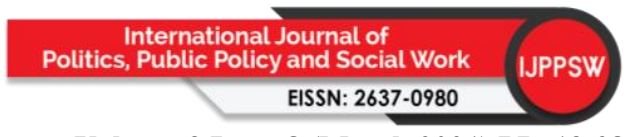

Volume 3 Issue 8 (March 2021) PP. 13-28 DOI: 10.35631/IJPPSW.38002

previous literature, the social protection system should compose of financial aid, human services, and accessible facilities. As such, we must take the opportunity of the post-pandemic world to build back better, echoing the core message by the United Nations for 2021's International Day of Persons with Disabilities. Having said that, future studies must expand on this particular topic by engaging other stakeholders such as parent groups as well as gathering qualitative data.

In this paper, the author also recommends immediate and medium-term measures to improve the social protection of disabled persons in Malaysia. The author hopes the present paper encourages local scholars and activists, especially among disabled persons themselves, to critically interrogate other aspects of the local economic system in relation to disabled persons' livelihood. Through concentrated efforts of academics and advocates, we can gradually redesign our societal arrangement to better benefit every Malaysian citizen, including persons with impairment and/or chronic illness.

\section{References}

Abo, N., \& Ayao, A. (2021). The compounded threat of COVID-19 and armed conflict in Mindanao. In Baysa-Barredo, J.M., Khoo, Y.H., \& Wiratraman, H.P. (eds.), Southeast Asia, infected and interrupted: Elevating critical voices on the state of human rights and peace in the time of COVID-19, (pp. 53-55). Bangkok, Thailand: Strengthening Human Rights and Peace Research/Education in ASEAN/Southeast Asia Programme (SHAPE-SEA).

Adato, M., \& Bassett, L. (2009). Social protection to support vulnerable children and families: The potential of cash transfers to protect education, health and nutrition. AIDS Care, 21(S1), 60-75.

Balasubramanian, M. (2021). A report on the social protection response to COVID-19 for persons with disabilities, South Asian region. Retrieved from https://www. internationaldisabilityalliance.org/-social-protection-covid19

Banks, L.M., Davey, C., Shakespeare, T., \& Kuper, H. (2021). Disability-inclusive responses to COVID-19: Lessons learnt from research on social protection in low- and middleincome countries. World Development, 137. Retrieved from https://www.ncbi. nlm.nih.gov/pmc/articles/PMC7455235/

Basrianto, F. (2021). Indonesian social care institutions: Potential death chambers in the midst of COVID-19. In Baysa-Barredo, J.M., Khoo, Y.H., \& Wiratraman, H.P. (eds.), Southeast Asia, infected and interrupted: Elevating critical voices on the state of human rights and peace in the time of COVID-19, (pp. 96-97). Bangkok, Thailand: Strengthening Human Rights and Peace Research/Education in ASEAN/Southeast Asia Programme (SHAPE-SEA).

Brucker, D.L., \& Scally, C.P. (2015). Linking public housing, employment, and disability benefits for working-age people with disabilities. Housing and Society, 42(2), 126-147.

Chen, L. (2021). Securitization of COVID-19 in Timor-Leste: A gender perspective. In BaysaBarredo, J.M., Khoo, Y.H., \& Wiratraman, H.P. (eds.), Southeast Asia, infected and interrupted: Elevating critical voices on the state of human rights and peace in the time of COVID-19, (pp. 31-34). Bangkok, Thailand: Strengthening Human Rights and Peace Research/Education in ASEAN/Southeast Asia Programme (SHAPE-SEA).

Jabatan Kebajikan Masyarakat Malaysia. (2021a). Bantuan OKU tidak berupaya bekerja. Retrieved from https://www.jkm.gov.my/jkm/index.php?r=portal/left\&id=T2FDeHJ Mei9nZVN4UWxRdlRLNytrUT09 


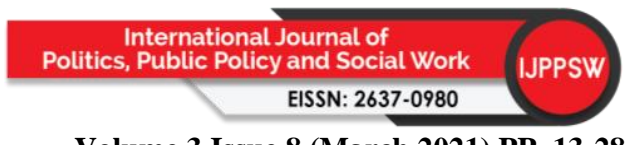

Volume 3 Issue 8 (March 2021) PP. 13-28 DOI: 10.35631/IJPPSW.38002

Jabatan Kebajikan Masyarakat Malaysia. (2021b). Elaun pekerja cacat. Retrieved from https://www.jkm.gov.my/jkm/index.php?r=portal/left\&id=akVMUTlrSU5mTOdCZys 3bzFCendNdz09

Juwitasari, R. (2021). Impacts of COVID-19 on the quality of children's nutrition in Indonesia. In Baysa-Barredo, J.M., Khoo, Y.H., \& Wiratraman, H.P. (eds.), Southeast Asia, infected and interrupted: Elevating critical voices on the state of human rights and peace in the time of COVID-19, (pp. 111-113). Bangkok, Thailand: Strengthening Human Rights and Peace Research/Education in ASEAN/Southeast Asia Programme (SHAPE-SEA).

Kementerian Pengajian Tinggi. (2021). Bantuan kewangan pelajar orang kurang upaya (OKU) di institusi pengajian tinggi (IPT). Retrieved from https://biasiswa.mohe.gov.my /bk_oku/

Lim, G., \& Wong, C. (2021). COVID-19 and Southeast Asian policy responses: Rethinking the 'human side' of the pandemic. In Baysa-Barredo, J.M., Khoo, Y.H., \& Wiratraman, H.P. (eds.), Southeast Asia, infected and interrupted: Elevating critical voices on the state of human rights and peace in the time of COVID-19, (pp. 9-11). Bangkok, Thailand: Strengthening Human Rights and Peace Research/Education in ASEAN/Southeast Asia Programme (SHAPE-SEA).

Mitra, S., Palmer, M., Kim, H., Mont, D., \& Groce, N. (2017). Extra costs of living with a disability: A review and agenda for research. Disability and Health Journal, 1-10. Retrieved from https://core.ac.uk/download/pdf/111012189.pdf

Mohamad, H.F. (2020, July 10). Had pendapatan kemiskinan dinaikkan dari RM980 kepada RM2,208. Berita Harian. Retrieved from https://www.bharian.com.my/bisnes/lainlain/2020/07/709264/had-pendapatan-kemiskinan-dinaikkan-dari-rm980-kepada$\operatorname{rm} 2208$

Nasir, M.N.A. (2020). The socio-economic situation of disabled persons in Malaysia. International Journal of Business, Economics and Law, 23(1), 74-82.

Nasir, M.N.A., \& Efendi, A.N.A.E. (2020a). Legal and policy basis for Bahasa Isyarat Malaysia interpretation services. International Journal of Law, Government and Communication, 5(21), 45-57.

Nasir, M.N.A., \& Efendi, A.N.A.E. (2020b). Vagrants, entrepreneurs or desperate people? Legal and media discourse on blind tissue sellers. Malaysian Journal of Social Administration, 14(2), 19-38.

Nelson, R.H., Ram, B., \& Majumder, M.A. (2020). Disability and contingency care, The American Journal of Bioethics, 20(7), 190-192.

Nguyen, T. (2021). Realising rice and rights: The role of civil society in realising the right to food in Vietnam during COVID-19. In Baysa-Barredo, J.M., Khoo, Y.H., \& Wiratraman, H.P. (eds.), Southeast Asia, infected and interrupted: Elevating critical voices on the state of human rights and peace in the time of COVID-19, (pp. 121-124). Bangkok, Thailand: Strengthening Human Rights and Peace Research/Education in ASEAN/Southeast Asia Programme (SHAPE-SEA).

Palmer, M., Williams, J., \& McPake, B. (2016). The cost of disability in a low income country. Retrieved from https://www.un.org/development/desa/disabilities/wp-content/uploads /sites/15/2016/02/The-Cost-of-Disability-in-a-Low-Income-Country.pdf

Pinol, M. (2021). COVID-19 in Cambodia and the benefits of democratic leadership. In BaysaBarredo, J.M., Khoo, Y.H., \& Wiratraman, H.P. (eds.), Southeast Asia, infected and interrupted: Elevating critical voices on the state of human rights and peace in the time of COVID-19, (pp. 50-52). Bangkok, Thailand: Strengthening Human Rights and Peace Research/Education in ASEAN/Southeast Asia Programme (SHAPE-SEA). 
PM cadang naikkan kadar bantuan bulanan JKM (2020, Aug 30), Harian Metro. Retrieved from https://www.hmetro.com.my/mutakhir/2020/08/615509/pm-cadang-naikkan-ka dar-bantuan-bulanan-jkm

Romano, A.C. (2020). Inclusion of persons with disability in social protection for COVID-19 recovery and beyond. Retrieved from https://socialprotection.org/discover/blog/ inclusion-persons-disabilities-social-protection-covid-19-recovery-and-beyond

Rumpia, J.R. (2021). At the brink of national terror: Repressive state apparatus in Indonesia's COVID-19 situation. In Baysa-Barredo, J.M., Khoo, Y.H., \& Wiratraman, H.P. (eds.), Southeast Asia, infected and interrupted: Elevating critical voices on the state of human rights and peace in the time of COVID-19, (pp. 35-37). Bangkok, Thailand: Strengthening Human Rights and Peace Research/Education in ASEAN/Southeast Asia Programme (SHAPE-SEA).

Sabatello, M., Landes, S.D., \& McDonald, K.E. (2020). People with disabilities in COVID-19: Fixing our priorities. The American Journal of Bioethics, 20(7), 187-190.

Santamaria, B.T.D. (2021). A dangerous message: Problematic implications of the military responses to COVID-19 in the Philippines. In Baysa-Barredo, J.M., Khoo, Y.H., \& Wiratraman, H.P. (eds.), Southeast Asia, infected and interrupted: Elevating critical voices on the state of human rights and peace in the time of COVID-19, (pp. 28-30). Bangkok, Thailand: Strengthening Human Rights and Peace Research/Education in ASEAN/Southeast Asia Programme (SHAPE-SEA).

Senjam, S.S. (2020). Impact of COVID-19 pandemic on people living with visual disability. Indian Journal of Ophthalmology, 68(7), 1367-1370.

Sison, A.M.A. (2021). Protecting rights while protecting lives: Do human rights give way in a state of emergency?. In Baysa-Barredo, J.M., Khoo, Y.H., \& Wiratraman, H.P. (eds.), Southeast Asia, infected and interrupted: Elevating critical voices on the state of human rights and peace in the time of COVID-19, (pp. 25-27). Bangkok, Thailand: Strengthening Human Rights and Peace Research/Education in ASEAN/Southeast Asia Programme (SHAPE-SEA).

Smith, N., Middleton, S., Ashton-Brooks, K., Cox, L., Dobson, B., \& Reith, L. (2004). Disabled people's costs of living: More than you would think. York: Joseph Rowntree Foundation.

Tantirapan, P. (2021). Enough is enough: Saving Thailand from a democratic crisis amid COVID-19. In Baysa-Barredo, J.M., Khoo, Y.H., \& Wiratraman, H.P. (eds.), Southeast Asia, infected and interrupted: Elevating critical voices on the state of human rights and peace in the time of COVID-19, (pp. 56-58). Bangkok, Thailand: Strengthening Human Rights and Peace Research/Education in ASEAN/Southeast Asia Programme (SHAPE-SEA).

UN Human Rights. (2020). COVID-19 and the rights of persons with disabilities: Guidance. Retrieved from https://www.ohchr.org/Documents/Issues/Disability/COVID-19_and_ The_Rights_of_Persons_with_Disabilities.pdf

Wartawan MalaysiaGazette. (2020, July 10). Pendapatan Garis Kemiskinan baharu dinaikkan kepada RM2,208 sebulan. MalaysiaGazette. Retrieved from https://malaysiagazette.com

/2020/07/10/pendapatan-garis-kemiskinan-baharu-dinaikkan-kepada-rm2208-sebulan/ 